\title{
Ocularcentrism in Singapore: A Preliminary Analysis of Architecture
}

\author{
Nathan Bullock \\ Duke University, North Carolina, USA
}

\begin{abstract}
The critique of ocularcentrism is commonplace in feminist theory but still requires additional deconstruction outside of Western philosophy. This paper takes that critique to Singapore and the domain of its modern architecture. Through an explanation of ocularcentrism and its impact on Singaporean architecture it is argued that the values of colonialism are visibly present despite the city-state's official post-colonial status. This paper connects the critique of ocularcentrism across three categories of architecture in Singapore - the Housing Development Board (HDB) public housing, the central business district (CBD) and the vernacular architecture of Kampong Glam. It concludes by examining the options for resistance and alternatives for space and architecture presented by Singaporean architects, theorists and critics.
\end{abstract}

Keywords: feminism, architectural theory, Singapore, modernism

$\mathrm{L}$ ife in the tropics makes full use of the five senses: the heat and humidity stand out for most people but are accompanied by equally potent smells, tastes, and sights. Despite its multisensory riches, colonialism and the architectures of control that were brought with it, determined that sight was the most important of these otherwise equally necessary human senses. The primacy of vision in European and Eurocentric philosophy has been well traced by the seminal works of Martin Jay (1988a, 1988b, 1993) and the trenchant critiques he identifies in French thought. In Downcast Eyes, Jay (1993) outlines the work of Hans Jonas (1966) and René Descartes (2013) who took their lead from Aristotle and Plato in reaching the conclusion that sight is the most valuable of the five physical senses for experiencing the world. As a phenomenologist, Jonas begins his essay 'The Nobility of Sight' with the now trite observation that, "Since the days of Greek philosophy sight has been hailed as the most excellent of the senses" (1966, p. 135). The fact that the power of vision and the privileged place of sight among the senses have been with us since the foundations of Western thought is precisely what warrants its critique by JeanPaul Sartre (1964), Luce Irigaray (1985), Elizabeth Grosz (2001), Peg Rawes (2007) and many others within and outside feminism. The history of this denigration, as Jay terms it, has not, however, resulted in ocularcentrism's evacuation from the guiding values of Anglo-American 


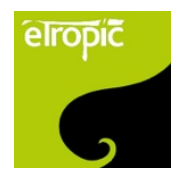

culture and its global corollaries, or the colonial and postcolonial spaces European modernism inhabits.

This type of modernism can perhaps best be viewed (and felt) in the domain of architecture. Most notably in this vein was the style of International Modernism - a thoroughly Euro-American form of modernity no more international than the brotherhood of male architects who established and codified it. Other related genres include Brutalism and the modern skyscraper. If it is given that ocularcentrism as a central tenet of European modernism then it becomes worthwhile to test its applicability in a form less commonly analysed and in a geography outside the boundaries of the Western hemisphere. Thus, this paper proposes to consider the existence and influence of ocularcentrism in Singapore by beginning with an analysis of architecture in three realms: public housing, the central business district, and the vernacular typologies in the conservation district Kampong Glam.

\section{The Singapore Context}

Singapore is placed, and has placed itself, in the discourses and narratives of the Asian Tiger economies which experienced exceptional growth and development in the latter half of the $20^{\text {th }}$ century, and the global cities network, an endless list of rankings and sophistic prestige. ${ }^{1}$ The country's colonial history spans more than a century of British rule and its one-party system postindependence maintains the "rule by elites" nature of colonial governance. The People's Action Party (PAP) has maintained strict control over policies relating to urban planning and development and has guided or approved most, if not all, architectural projects in the city-state. In a study conducted during the 1970s, researcher Kalyani K. Mehta summarized Singaporean society as "highly urbanized, materialistic, competitive, and cosmopolitan" (1983, p. 131). She continued, "Although the government is trying to build a distinctively Singaporean culture, that aim has not yet become a reality" (1983, p. 131-132). This was a study on suicide whose conclusions still resonate over thirty years later. For instance, such strident criticism can be found in sources ranging from cyberpunk author William Gibson who famously coined the epigram "Disneyland with the Death Penalty" (1993) to Rem Koolhaas's portrayal of the city-state as "a more relaxed version of Sparta" (1995, p. 1077). Finnish architect and critic Juhani Pallasmaa offers a rich diagram of this critique's connection and application to architecture in The Eyes of the Skin where he writes, "The inhumanity of contemporary architecture and cities can be understood as the consequence of the neglect of the body and the senses, and an imbalance in our sensory system" (2012, p. 21). This phallocentric scopic regime of modernity is notably dominant in Singapore where ocularcentrism visibly takes hold in the urban built environment.

As its critics have largely pointed out, ocularcentrism betrays a phallocentric positioning of the subject in a world that is "geometrically isotropic, rectilinear, abstract, and uniform" (Jay, 1988b,

\footnotetext{
${ }^{1}$ See: Saskia Sassen's Cities in a World Economy (2012) and Aihwa Ong's Neoliberalism as Exception (2006), for beginners.
} 
p. 6). This process of ordering and knowing places is conducted "with its illusion of homogeneous three-dimensional space seen with a God's-eye-view from afar" (1988b, p. 16-17). It follows then that for the architect to design and take a God's-eye-view "sight is the only sense in which the advantage lies not in proximity but in distance" (Jonas, 1966, p. 149). In the history of art and architecture, this style has been summarized as a "lucid, linear, solid, fixed, planimetric, closed form" (Jay, 1988b, p. 16). As Jay reads from Jonas, one of the primary implications of this philosophy is that "it thus tends to elevate static Being over dynamic Becoming, fixed essences over ephemeral appearances" (Jay, 1993, p. 24). A second key implication Jay elicits from Jonas is that "the externality of sight allows the observer to avoid direct engagement with the object of his gaze" (Jay, 1993, p. 25). To synthesize, there are three important thematic forces at work in an ocularcentric scopic regime. First, the visual elements of form and design that are described above and which are implemented in literal and physical ways. Second, the importance of distance from the viewing subject and the objects which are viewed, as well as the relative anonymity that this distance provides for the beholder. Third, the necessity of fixity and stasis that is central to the uniformity of shapes as much as for the field of vision itself. It is with this theoretical framework for analysis and critique that I will investigate the vestiges of ocularcentrism in the architecture of Singapore.

\section{The Housing Development Board (HDB) Flats}

It would be misleading, if visually appealing, to start with the most recent architectural projects sparkling to set Singapore's skyline on par with its previous colonial metropole - such as the Marina Bay Sands, by Moshe Safdie and Reflections at Keppel Bay, by Daniel Liebeskind. Instead of such an ocularcentric approach the analysis of this phallocentric scopic regime instead will start with the public housing blocks of the Housing Development Board (HDB). The vast majority of Singaporeans reside in HDBs of various sizes but similar layouts. These high-rise housing estates are located throughout the island and perfectly fit the descriptors of isotropic and rectilinearity with a uniformity that has made them easily replicable from the 1960 s to today (Figure 1).

In his excellent book on the creation of the first HDBs, historian Loh Kah Seng (2013) chronicles the ocularcentric scopic regime behind the design, planning, and politics of the government's directed construction. In an interview with one of the architects, we learn that "[they] were given a guideline - one-room, two-room, three-room - the size of the unit, and the type of materials [they] were allowed to use, and the structure was usually concrete, so it was very straightforward" (Chee quoted in Loh, 2013, p. 188). Sociologist Chua Beng-Huat deftly showed how this architectural form amounts to a "placeless continuum of similarity" (1991, p. 207). He provides a lengthy description of the austerely uniform style of public housing in Singapore only to then reveal that the quote was actually of a public housing estate in East Germany. This placelessness is startlingly underlined by the fact that "guided by the prototype, all spaces in an HDB new town are planned spaces which abide by a geometrical order. Even undeveloped spaces are left so intentionally as reserved sites" (1991, p. 211). A prototype so nihilistic that it may have originated 
in East Germany. While the material conditions of the urban environment may not be as desperate as they were in East Germany, Chua is emphatic that "it should be noted that the generous green spaces between blocks are not meant to be used by residents. They are visual, green relief from the concrete blocks of buildings" (1991, p. 212). Chua's observation is a foreshadowing of the greenwashing that would take place in today's Singapore.

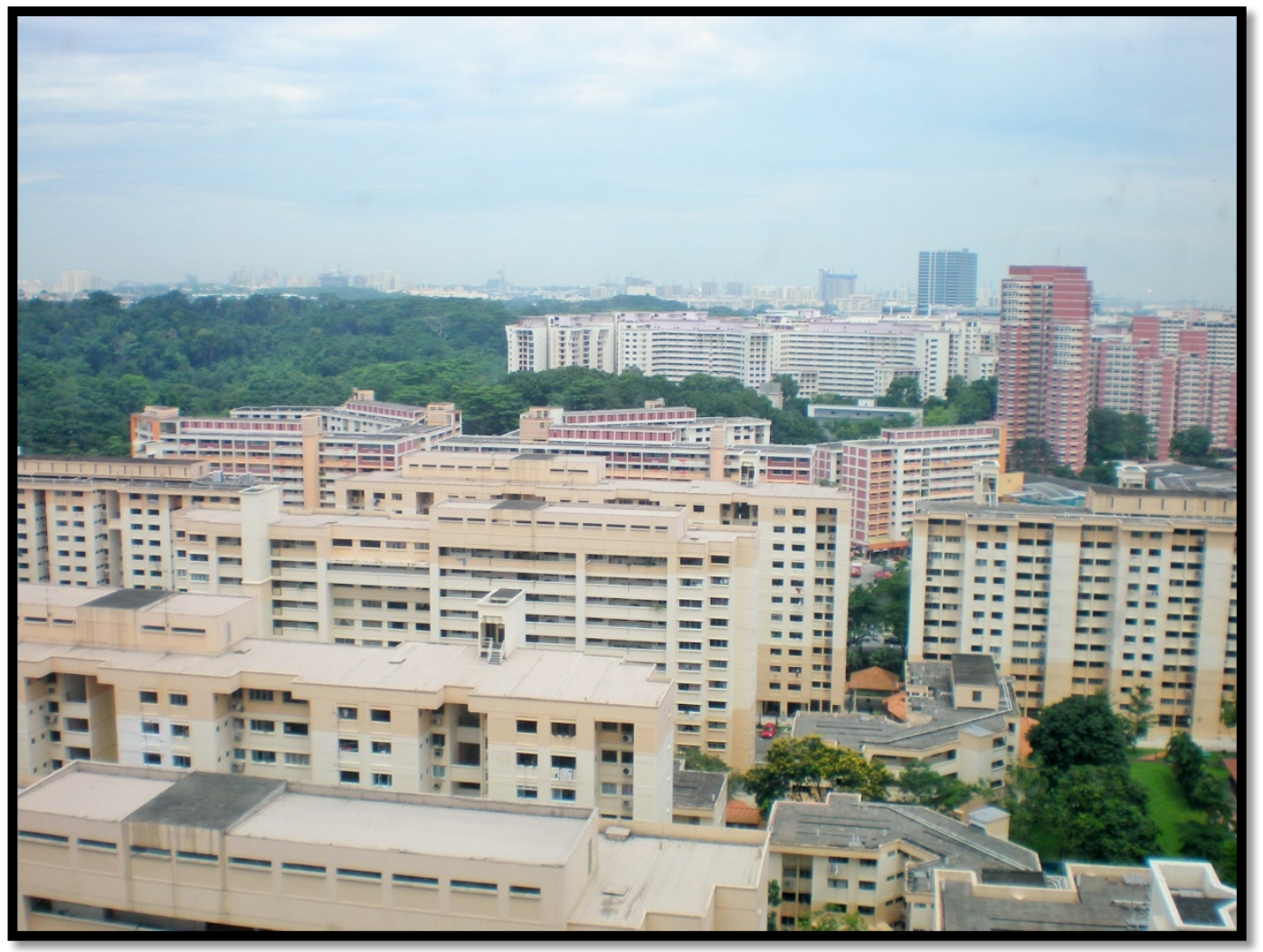

Figure 1: HDB blocks in Bukit Batok, Singapore. Author's photograph (2010)

The kampong (village) Bukit Ho Swee, whose destruction by fire, Loh (2013) identifies as the catalyst for the implementation of the large scale massive HDB flats, was known officially as a "black area" (黑区) - a place of gangs, crime, violence, poverty, and dirt. The government's inability to know and see with a clear eye what was occurring (much less, understand the particular social, cultural, and economic structures) in this settlement led to impatient pleas and plans for residents to relocate. In contrast, the residents' "notions of darkness and light, stuffiness and fresh air, and sanitation and dirt were conditioned by the physical environment and differed from Western-centric views" (2013, p. 60). Thus, the indigenous experience of space and architecture exposes the phallocentric conceptions of space and the build environment that the newly independent government had imbibed from the British - despite the government's anticolonial stance. Chua reaches the same conclusion in his long-term research on the transformation of public spaces and social life in Singapore: "This elimination of the different cultural expressions in the residential environment and replacing them with standardized high- 
rise blocks is essentially a transformation of the Vernacular to the Modernist environment" (1991, p. 204). The vernacular's ability to change, its flexibility and becoming-ness, were ungovernable in the logic of Modernism and had to be frozen in the concrete walls of HDB flats.

This fixity of the repetitive concrete housing blocks was part of the static being that the state demands of its citizens. Loh recounts that the "government shared with the British regime a hostility towards unauthorized wooden housing. In 1960, the [government] prohibited unauthorized housing on state or Board lands...By mid-1962, [it] had demolished 615 unauthorized buildings on state land since coming to power" (2013, p. 185). Temporary wooden housing in the kampong was the ultimate vernacular form of domestic architecture. It was pliable, made of easily attainable materials including wood, attap palm leaves, and at times tin or other cheap and flexible metals. Its ephemerality was seen as a threat by the ocularcentric state - as had been the case for the British colonial administration - in its inability to be a distant viewer safe from the returned gaze of its citizen-objects. The government took this approach further by instituting policy measures to ensure racial quotas for each block. In 1989 the "Ethnic Integration Policy" was adopted which set limits on the maximum number for each recognized group in individual HDB estates. A neighborhood could be no more than $22 \%$ Malay, $84 \%$ Chinese, and $10 \%$ Indian and Other (National Library Board, n.d.). These quotas necessarily required residents to likewise limit themselves to an identity to fit this ideology of race - one that was seen as a static and fixed essence.

\section{The Central Business District}

The architecture of the HDB estate is not acting alone in eliciting these ocularcentric responses. The central business district has filled itself with the works of the "great masters" of contemporary modernism including I.M. Pei, Philip Johnson, Kevin Roche, and Kenzo Tange. Nearly the entirety of the CBD is an homage to Western philosophy's phallocentric scopic regime. Each modernist skyscraper reflects (in its form and content) the attention to vision as the primary sensory experience. Singapore's skyline screams with its desire to be seen, to be viewed, to be recognized. Prior to the post-WWII boom in economic growth exemplified in the now ubiquitous skycrapers, the leading landmarks were still the steeple of St. Andrew's Cathedral and the dome of the former Supreme Court. In 1986 two buildings were created which stand out for their adherence to the characteristics of ocularcentric Modernism. One Raffles Place, or the Overseas Union Bank (OUB) Centre, has the appearance of a cutting triangular structure with 60 floors. Designed by Japanese architect Kenzo Tange and made of reinforced concrete and aluminum, it was the tallest building outside North America when it was completed. The closed form delineates space with precision both on the ground and in the sky. The banking and financial centers of corporate headquarters and multinational firms are static and unchanging in their offices here just as is their role in the Singaporean economy and their places in the central business district. Similarly, the Swissôtel located at 2 Stamford Road is a cylinder of Modernist uniformity and was originally a Westin hotel (Figure 2). 


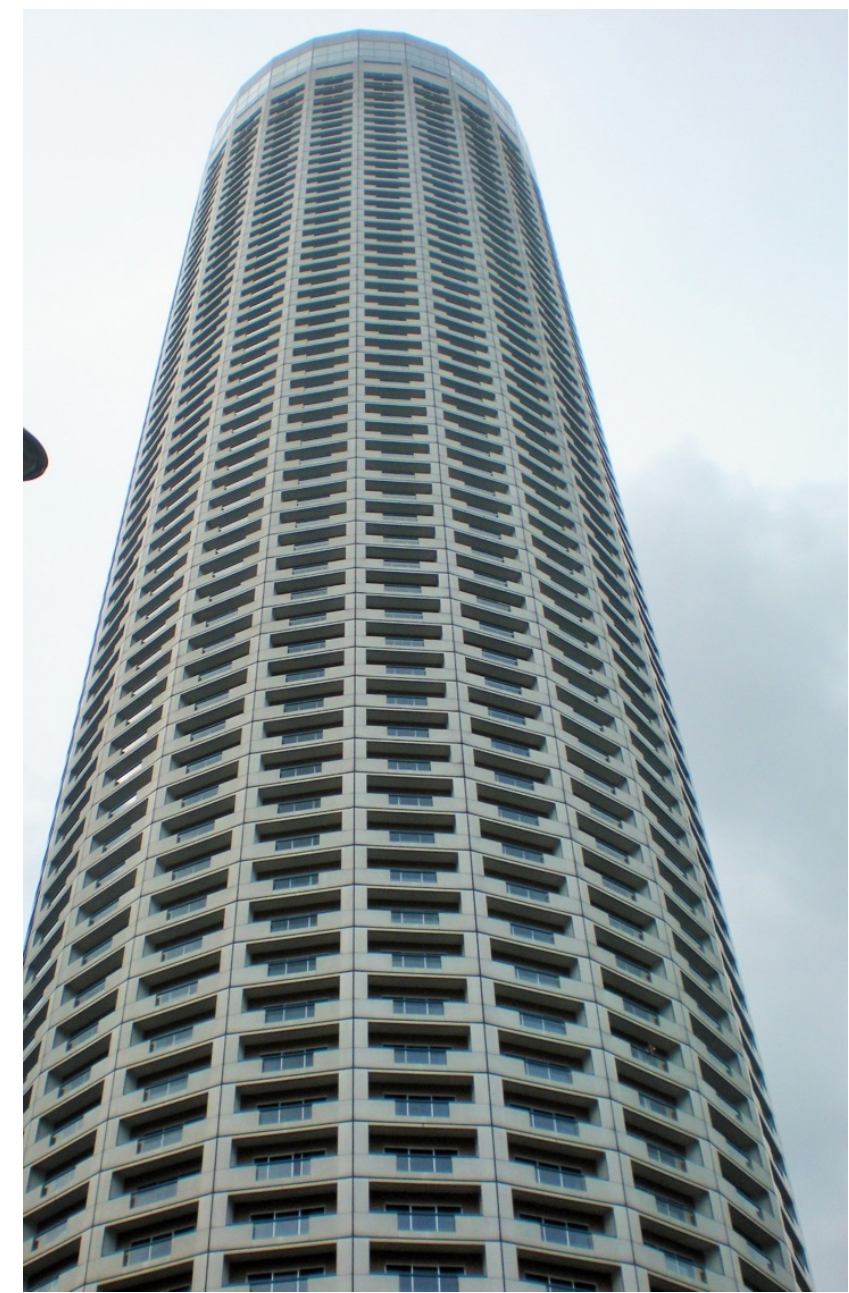

Figure 2: Swissôtel, 2 Stamford Road, Singapore - I.M. Pei (1986). Author's Photograph (2010)

Designed by American, Chinese born, architect I.M. Pei, it was the tallest hotel building in the world at its completion. With multiple bars and restaurants providing viewing decks on the top floors, this building is perhaps the closest to the architecture of the panopticon allowing viewers to look out over the city without being seen. Furthermore, it is iconic of the wealth that allows for a distance that is both physical and social between those who have access to the "God's-eyeview" and those who do not. Even with its cylindrical curves it is decidedly fixed, frigidly solid, and immobile as it sits atop the peopled flows of the underground mass rapid transit station. Singaporean architect and theorist William Lim makes it clear that "Mainstream foreign corporate architects were preferred in the endeavour to make Singapore a modernist city in the visual imagery of American capitalism" (2005, p. 156). From the early high-rises in the 1950s, to the 70 s and 80 s and now in the latest Marina Bay Financial Centre (Figure 3), the lux and lumen testify to the "ultimately identitarian monism" that Jay identifies in the philosophy of Descartes (Jay, 1993, p. 80). 


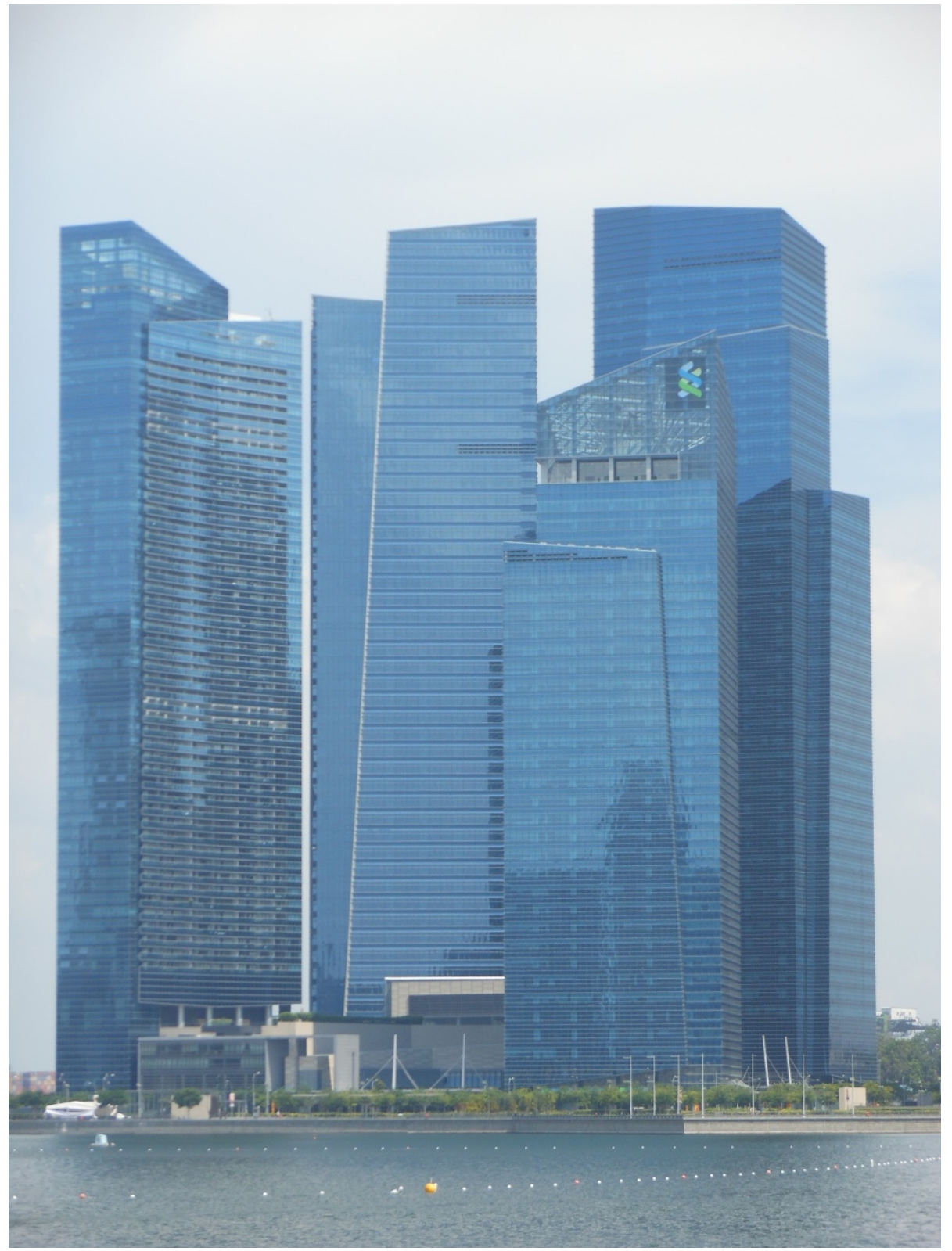

Figure 3: Marina Bay Financial Centre - Kohn Pederson Fox (2012). Author's photograph (2012)

Modernism's disregard for local identity and architectural features does not impede its drive for superlative categorisation of the visual. Marina Bay Financial Centre was designed by Kohn Pederson Fox (KPF) and completed in 2012. KPF seems to be the type of foreign corporate architecture firm Lim had in mind as purveyors of "the visual imagery of American capitalism" (2005, p. 156). This description is echoed in Patrick Bingham-Hall's analysis after the building's completion that it could be mistaken for the likes of Minneapolis as a "perversely neutral...tropical tribute to the American downtown skylines of the early 1980s" (2012, p. 111). 


\section{The Conservation District Kampong Glam}

A final area in which the pervasive effects of ocularcentrism can be seen in Singaporean architecture is through historic conservation of architectural heritage. Conservation of historic buildings and districts in Singapore has revealed to be one that has as its end the perpetuation of a visual environment that appeals to the touristic gaze. Kampong Glam is one of three main cultural and architectural conservation districts in Singapore based on the state's racial categories of Chinese, Malay, Indian, and Other which come from the original colonial town plan of 1822. Kampong Glam is the district ascribed to Malays who are seen as an indigenous population as opposed to the migrants from China, India, and elsewhere. The architectural centre of this district is the Sultan Mosque and its neighboring pedestrianised streets filled with shops and restaurants catering to mostly foreign visitors (Figure 4).

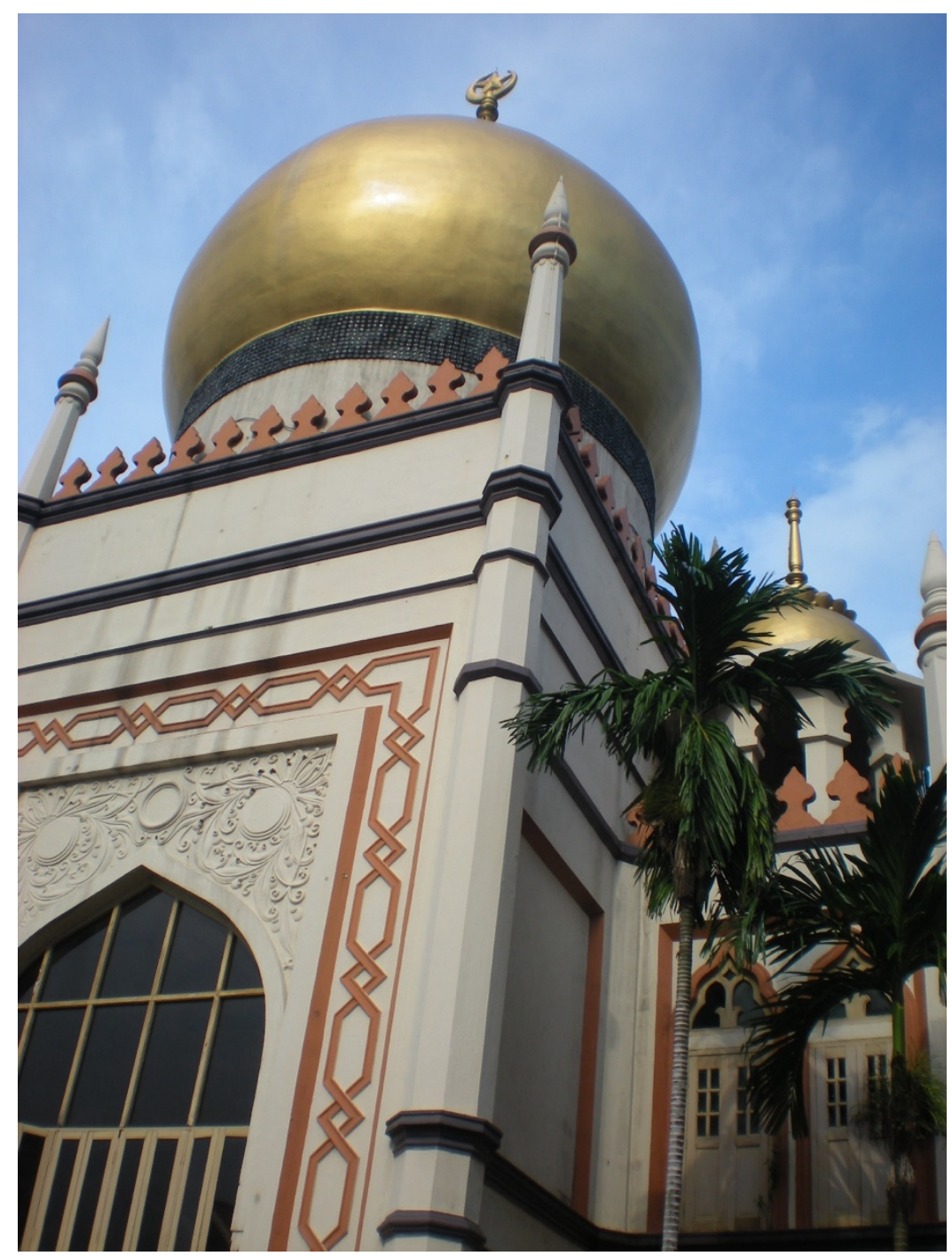

Figure 4: Sultan Mosque, Kampong Glam, Singapore. Author's photograph (2010). 
The simplification of cultural identities and the erasure of differences is most evident in Kampong Glam's official designation as a Malay area. It firstly creates the misperception that other areas of Singapore were not as populated by Malay peoples and that this area was monocultural and singularly segregated by ethnicity. Its place names include Arab Street, Baghdad Street, and Kandahar Street - all indicative of the plurality of peoples who settled and mixed in this area. Yeoh and Huang explain in their study of the area that "by selectively choosing which area/history should remain hidden, state conservation-redevelopment practices are complicit in simultaneously erasing and inventing heritage... and without consultation with the occupants of the area, ultimately defeats this purpose" (Yeoh \& Huang, 1996, p. 420-421).

Other authors in geography and cultural studies have variously described the process of architectural preservation as Disneyfication and creative destruction to architourism and urban renewal (Yeoh \& Huang, 1996; Wong \& Tan, 2004; Henderson, 2011; Chang, 2010; Yeoh \& Kong, 1994; Chang \& Huang, 2005; Chang \& Teo, 2009; Dobbs 2003). Each of these studies reveals that the goal of state-driven preservation attempts are not to create popular projects that protect cultural heritage and material as found in architectural design, but to fix in time and space the acceptable meanings and identities that are legible to the state, citizens, and tourists who may also gaze upon the scene with a distance that protects them from being viewed themselves. This district has become architecturally and functionally a space of ocularcenrism - the buildings functions include being looked at, photographed, shopping, eating, and touring. The plethora of shophouses or Chinese terrace houses as the leading architectural typology of the area calls into question the act of conservation as so few vernacular Malay buildings actually exist here. Like the kampong housing of early Singapore discussed by Loh (2013) and Imran bin Tajudeen (2017, $2012,2010)$ the traditional architecture of Kampong Glam was previously not a typology which privileged sight over the other senses. The importance of the sense of touch and feeling with regards to the climate, as well as the blocking of sight to create shade and privacy, were key architectural elements at odds with the ocularcentrism of modernism.

\section{Impacts of, and Reactions to, Ocularcentrism in Architecture}

The devaluing and discounting of the corporeal as critiqued in the work of Juhani Pallasmaa (2012) and Elizabeth Grosz (2001) guide this discussion of ocularcentrism in the architecture of Singapore. Further insights are provided by considering the active role architecture - whether the structures of corporate buildings, the living spaces of HDB flats, or the façade-focused conservation of historic buildings - plays on a city's citizens. Pallasmaa comments that "The art of the eye has certainly produced imposing and thought-provoking structures, but it has not facilitated human rootedness in the world" (2012, p. 22). The Swissôtel (Figure 2) is one such example that enacts a panoptic structure. It's curved shape and glass windows - not only on the hotel rooms but also on the top floor restaurant and bar - provide the opportunity for panoptic viewing by those from the outside and those whose budgets can afford the top shelf drinks. It is 
certainly an "imposing and thought-provoking structure" but as a hotel it is also one that is inherently against "human rootedness" as people come and go on temporary visits and staycations. Indeed, Singaporeans could easily be defined by the colonial deracination that has been exacerbated by the government's merging of its ideology of race with housing policies. Racial quotas for HDB estates insist that residents not be rooted to the local and familiar but remain constantly aware of theirs and their neighbors' difference. Chua noted in his analysis of corridor space in HDBs, "the shut door stands as evidence and symbol, to the residents themselves, of the anti-social character of the high-rise environment. It is a particularly common complaint among resettled villagers whose doors were never shut during the day in the village" (1991, p. 213). Along this vein, Pallasmaa continues, "Modernist design at large has housed the intellect and the eye, but it has left the body and the other senses, as well as our memories, imagination and dreams, homeless" (2012, p. 22). One need look no further than the campaigns aimed at creating a sense of nationalism and increasing the birth rate to witness the homeless imagination. From each successive National Day's song and dance to newer Singapore Day festivals being held abroad, homeless dreams and memories are staged with vigor. Chua's analysis of the common areas of HDBs is telling here, "it should be noted that most void decks are not used at all. This accounts for the generalized sense of emptiness throughout the neighborhood" (1991, p. 214). Singaporean architect William Lim's take on these public housing estates is in agreement that they are "built in simplistic and rigid modernist style and lacking in excitement, character and identity are fixed in repetitive, boring layouts and are found all over the island. The uninspiring architecture of Singapore's urban living space reflects its cultural rootlessness" (2005, p. 156). Singaporean homelessness (in a country with an incredibly low homeless population) is expressed most poignantly by the poet and playwright Alfian Sa'at in his poem "Singapore You Are Not My Country" (1998, pp.38-41). In it he mourns,

"This has become an island of walls.

Asylum walls, factory walls, school walls, the walls of the midnight Istana."

He challenges the architecture asking,

"And how can you call yourself a country, you terrible hallucination

of highways and cranes and condominiums ten minutes' drive from the MRT?"

He continues in his rhetorical reply,

"Tell that to the pawns of The Upgrading Empire who penetrate their phalluses into heartlands to plant Lego cineplexes Tupperware playgrounds suicidal balconies carnal parks of cardboard and condoms and before we know it we are a colony once again."

In the lyrical speed of his enjambment one senses an unfettered anguish flowing at a rate to mirror the unrestrained vertical accumulation of architecture driven by ocularcentrism. As Sa'at reaches the end he accuses once more,

"You are not a country you are a construction from spare parts" 


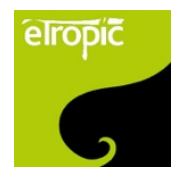

And in the final stanza he concludes,

"I have lost a country to images, it is as simple as that."

Sa'at's indictment calls out each of the themes of ocularcentrism: design based on a view from above, formal shapes that are geometric and linear, and the permanence of fixed form. The uniform, Eurocentric and Anglo-American designs of Lego and Tupperware are reminiscent of the English Gothic and neoclassical styles of British imperialism. Now the innermost parts of the island are penetrated by phallic high rises rather than by "rapist" colonizers from England and Japan. The master planning of these cineplexes, playgrounds, and parks are done by the anonymous planners of the Urban Redevelopment Authority away from public scrutiny and imposed by top-down regulations. The uniformity and fixity is seen in the "island of walls" applicable to any and every setting - the asylum, factory, and school - these landscapes ring of the examples used by Michel Foucault in Discipline and Punish (1995).

Phallocularcentrism's triumph in Singapore is not without its challengers and resistors. Sa'at's poetic work from 1998 resonates textually and aurally with a more recent medium. Filmmaker Tan Pin Pin's documentary "To Singapore, with Love" (2014), about Singaporeans living in exile, is equally provocative as indicated by its having been banned in the city-state (even after her appeal). Her next film "In Time to Come" (2017) documents the mundane spaces and marginal architectures of Singaporeans' lives in a way that replicates a time capsule. These two art forms complement each other in their critical commentary on, and rejection of, the ocularcentrism of the state in Singapore's urban built environment.

Island-wide it can be observed that "the dominance of the eye and the suppression of the other senses tend to push us into detachment, isolation and exteriority" (Pallasmaa, 2012, p. 22). While architecture may be so ubiquitous that its visual elements often do not warrant a second glance, its actions on users are very real and often psychologically disturbing. This is especially the case for architecture which is ocularcentric. The side-effects which Pallasmaa describes above are present in the examples provided from Singapore. Chua shows the detachment and isolation that exists when he analyzes the residents' committees formed in each HDB estate and rightly points out "that these committees are organized is itself indicative of the difficulties of the spontaneous development of acquaintances in high-rise environment" (1991, p. 216). In considering the widespread impact of the total environment, exteriority and detachment have been evidenced by public surveys which have shown that nearly half of young Singaporeans (ages 19-30) would give up their citizenship and emigrate if given the option (Soon \& Leong, 2010). This sense of urban modernist detachment and isolation extends beyond emigration and denaturalization to the most insidious form of escapism - suicide. Suicide in Singapore is both a symptom of, and a resistance to, the continued colonial imposition of European humanism and modernity by the post-colonial government. 
Suicide in Singapore reached an all-time high in 2012 and is the cause of approximately two percent of deaths annually (AFP, 2014). What is most interesting is not the quantity of suicide cases per se but the style of death. Many of these occur in the HDB estate, although it has been reported to occur at the Swissôtel as well (Goh, 2015). Anecdotes are regularly found in multiple local media outlets online and in print. In one study of suicide from 1970-1974 (part of the major period of urbanisation and rehousing) it was found that $51 \%$ of the total number of suicides were committed by jumping from a high-rise housing complex. The researchers further commented, "Nowhere else in the world is this method so frequently used" (Chia, 1983, p. 120). In Haresh Sharma's play Model Citizens (2012) a young man and HDB dweller commits suicide because he is unable to change and disrupt the fixity of being and uniformity required by the state. Eric Khoo's 1997 film 12 Storeys (十二楼) begins with a scene of a young man jumping off an HDB high-rise apartment building. ${ }^{2}$ Sa'at's poem evocatively made the connection between imperial penetrating phalluses and suicidal balconies. It is important to dwell on the imperial nature of urbanisation and the architecture of European modernism as embraced by the Singaporean state to see the connections to relevant postcolonial theorists such as Frantz Fanon. Suicide is a form of violence and is additionally a form of resistance in that it is illegal and the survivor of an attempted suicide may be jailed and/or fined. Medical facilities which treat a survivor must report it to the police. In The Wretched of the Earth, Fanon unashamedly endorses violence in the colonial context: "For the colonized, this violence represents the absolute praxis" (1963, p. 44). Even as Singapore is celebrated for its safety and its minimalisation of violent crime, and despite any violent overthrow of the government being unlikely, violence exists in the form of the colonised subject turning on him or herself. Suicide is a violent form of resistance as "the colonized man liberates himself in and through violence" (1963, p. 44).

Art critic and activist Lee Weng Choy made a similar point in an essay titled, "Modernism with Modernity" (2004). He argues that Singapore's plethora of modernism in art and architecture is sirenic of the lack of what he defines as modernity - namely, a functioning civil society. He connects his critique as emanating from architect Rem Koolhaas's idiosyncratic reading of Singaporean space in "Singapore Songlines" where he opined, "in spite of its colossal substance, Singapore is doomed to remain a Potemkin metropolis" (Koolhaas, 1995, p. 1077). For Lee Weng Choy, Singapore's modernism represents "the manufactured consent of the masses" (2003, $p$. 27). Combined with Alfian Sa'at's poetic critique there is again space for revealing the connection to Fanon's decolonial imperative:

If the national government wants to be national it must govern by the people and for the people, for the disinherited and by the disinherited. No leader, whatever his worth, can replace the will of the people, and the national government, before concerning itself with international prestige, must first restore dignity to all citizens, furnish their minds, fill their eyes with human things

\footnotetext{
${ }^{2}$ More analysis of the urban landscape of Singapore in film can be found in L. Law, C.J.W.-L. Wee and F. McMullan's "Screening Singapore” (2011).
} 
and develop a human landscape for the sake of its enlightened and sovereign inhabitants. (1963, p. 144).

\section{Alternatives}

The distances described here between the architecture and the users emulates the distance of the previous colonial state and its foreign administrators. For the post-colonial government to perpetuate these practices and values in planning and architectural preservation presents an ethical dilemma. This lack of critical interrogation leads Singaporean architect William Lim to call for an ethical urbanism. He is responding to the way in which "colonial aesthetic dominance in the realm of civic projects, urban planning and public spaces greatly distorted visual images of the Asian urban environment and the appreciation of its past, and has continued to do so, well beyond the end of colonial rule" (Lim, 2005, p. 64). He makes robust connections between Modernist ocularcentrism in Singapore and the lack of local vitality in cultural productions and identity. As a way forward, Lim proposes "spaces of indeterminacy" as an antidote to this Modernist scopic regime of ocularcentrism. He paints them as "theatres with the potential to become effective instruments of contemporary intellectual, artistic, cultural and sociological discourses" (2005, p. 166). The more radical position that Lim would have us take is one that would enable us to believe without needing to see.

The importance of recognising this difference in spaces of indeterminacy - even as it is occluded in the official architectural history as Yeoh and Huang (1996) pointed out above - is to better understand the relationship between modernist and vernacular architectures in Singapore as well as for informing alternatives for future design. Such proposals have been shown to be feasible in Singapore in the works of Tay Kheng Soon and his firm Akitek Tenggara (Powell, 1997) and architect Philip Bay (Bay et al., 2006). One such example is Tay Kheng Soon's Modern Tropical House. It has a basis in the vernacular kampong house in which it is "oriented to catch the prevailing breezes, it has extensive use of water and planting...wide overhanging eaves, the opportunity to adjust the penetration of sunlight by the use of manually-operated blinds, secondary shading devices, and the restriction of air-conditioning" (Powell, 1997, p. 110). Tay adds, "The recovery of the senses is undoubtedly a total societal process. The ability to produce breakthrough qualities depend on this" (Tay quoted in Powell, 1997, p. 115). Kampong Glam as an historic district, and kampong housing as an architectural typology, can be recovered and presented as viable alternatives through the groundwork of the feminist critique presented in this paper. These vernacular typologies are ones that make use of the sense of touch and the presence of the body and the user.

Rawes suggests that "architects need to be mindful of the cultural, social and political limitations for expressing reality that exist in universal claims made for architecture's mechanical, technical and scientific methods" (2007, p. 68). The singular focus on sight and its claim to truth in the technical side of architectural design has limited it from reaching the reality of people's lived 


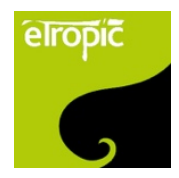

experiences. People experience buildings at the street level, on ground floors, and in between spaces, more often than from a rooftop or helicopter. The alternatives found in the work of Tay Kheng Soon and the vernacular Malay kampong are in line with the alternative approach of focusing on the margins and the spaces between buildings. As Grosz states, "The space in between things is the space in which things are undone, the space to the side and around, which is the space of subversion and fraying, the edges of any identity's limits" (2001, p. 93). This feminist approach of building for, in, and with the margins, and seeing the in between spaces as subversive, is both theoretically and practically powerful for offering a way forward for architecture that is more fully sensual.

\section{References}

AFP. (2014, July 30). Family Disconnect 'Drives Young Singaporeans to Suicide'. Retrieved November 23, 2014, from Yahoo News: https://sg.news.yahoo.com/family-disconnectdrives-young-singaporeans-suicide-140911288.html

Bay, J.-H., Wang, N., Liang, Q. and Kang, P. (2006). Socio-environmental dimensions in tropical semi-open spaces of high-rise housing in Singapore. In Bay, J.-H. and Ong, B.-L. (Eds.) Tropical Sustainable Architecture: Social and Environmental Dimensions (pp. 59-82). Burlington, MA: Architectural Press.

Bingham-Hall, P. (2012). A Guide to $21^{\text {st }}$ Century Singapore Architecture. Singapore: Pesaro Publishing.

Boon, C. H. (1983). Singapore - Part 1. In L. A. Headley (Ed.), Suicide in Asia and the Near East (pp. 101-127). Berkeley: University of California Press.

Chang, T. (2010). Bungalows, mansions and shophouses: Encounters in architourism. Geoforum, 41, 963-971.

Chang, T., \& Huang, S. (2005). Recreating place, replacing memory: Creative destruction at the Singapore River. Asia Pacific Viewpoint, 46(3), 267-280.

Chang, T., \& Teo, P. (2009). The Shophouse Hotel: Vernacular Heritage in a Creative City. Urban Studies, 46(2), 341-367.

Chua, B.-H. (1991). Modernism and the Vernacular: Transformation of Public Spaces and Social Life in Singapore. Journal of Architectural and Planning Research, 8(3), 203-221.

Descartes, R. (2013). Optics. In N. Mirzoeff (Ed.), The Visual Culture Reader (3rd ed., pp. 6065). New York: Routledge.

Dobbs, S. (2002). Urban Redevelopment and the Forced Eviction of the Lighters from the Singapore River. Singapore Journal of Tropical Geography, 22(3), 288-310.

Fanon, F. (1963). The Wretched of the Earth. New York: Grove Press.

Foucault, M. (1995). Discipline and Punish: the Birth of the Prison. (A. Sheridan, Trans.) New York: Vintage Books.

Gibson, W. (1993, September-October). Disneyland with the Death Penalty. WIRED. Retrieved from http://archive.wired.com/wired/archive/1.04/gibson_pr.html 
Goh, E. (2015). Another person falls to death at Swissôtel. Channel News Asia (3 Jun): http://www.channelnewsasia.com/news/singapore/another-person-falls-to-death-atswissotel-8259162.

Grosz, E. (2001). Architecture from the Outside: Essays on Virtual and Real Space. Cambridge: MIT Press.

Henderson, J. (2011). Hip heritage: The boutique hotel business in Singapore. Tourism and Hospitality Research, 11(3), 217-223.

Irigaray, L. (1985). Speculum of the Other Woman. Ithaca: Cornell University Press.

Jay, M. (1988a). The Rise of Hermeneutics and the Crisis of Ocularcentrism. Poetics Today, 9(2), 307-326.

Jay, M. (1988b). Scopic Regimes of Modernity. In H. Foster (Ed.), Vision and Visuality (pp. 223). Seattle: Bay Press.

Jay, M. (1993). Downcast Eyes: The Denigration of Vision in Twentieth-Century French Thought. Berkeley: University of California Press.

Jonas, H. (1966). The Nobility of Sight: A Study in the Phenomenology of the Senses. In The Phenomenon of Life: Toward a Philosophical Biology (pp. 135-156). New York: Harper \& Row.

Koolhaas, R. (1995). Singapore Songlines: Portrait of a Potemkin Metropolis...or Thirty Years of Tabula Rasa. In S, M, X, XL (pp. 1008-1087). New York: Monacelli Press.

Law, L., Wee, C.J.W.-L. \& McMullan, F. (2011). Screening Singapore: The Cinematic Landscape of Eric Khoo's Be with Me. Geographical Research, 49(4), 363-374.

Lee, W. C. (2004). Modernism without Modernity: New Public Art in Singapore. ArtAsiaPacific(39), 26-27.

Lim, W. S. (2005). Asian Ethical Urbanism: A Radical Postmodern Perspective. Singapore: World Scientific.

Loh, K. S. (2013). Squatters into Citizens: The 1961 Bukit Ho Swee Fire and the Making of Modern Singapore. Singapore: National University of Singapore Press.

Mehta, K. K. (1983). Singapore - Part 3. In L. A. Headley (Ed.), Suicide in Asia and the Near East (pp. 130-141). Berkeley: University of California Press.

National Library Board. (n.d.). Ethnic Integration Policy Implemented. Retrieved November 23, 2014, from HistorySG: http://eresources.nlb.gov.sg/history/events/d8fea656-d86e-46589509-974225951607

Ong, A. (2006). Neoliberalism as Exception: Mutations in Citizenship and Sovereignty. Durham: Duke University Press.

Pallasmaa, J. (2012). The Eyes of the Skin: Architecture and the Senses. Cornwall: John Wiley \& Sons.

Powell, R. (1997). Line, Edge \& Shade: The Search for a Design Language in Tropical Asia. Singapore: Page One Publishing.

Rawes, P. (2007). Irigaray for Architects. New York: Routledge.

Sa'at, A. (1998). Singapore You Are Not My Country. In One Fierce Hour (pp. 37-41). Singapore: Landmark Books. 


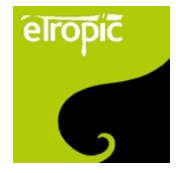

Sartre, J.-P. a. (1964). Black Orpheus. The Massachusetts Review, 6(1), 13-52.

Sassen, S. (2012). Cities in a World Economy (4th ed.). Thousand Oaks: SAGE.

Sharma, H. (2012). Model Citizens. Singapore: Epigram Books.

Soon, D., \& Leong, C.-H. (2010). A Study on Emigration Attitudes of Young Singaporeans. Singapore: Institute of Policy Studies.

Tajudeen, I. bin (2017). Colonial-Vernacular Houses of Java, Malaya, and Singapore in the Nineteenth and Early Twentieth Centuries. ABE Journal, 11, Retrieved January 11, 2018, from: http://journals.openedition.org/abe/3715

Tajudeen, I. bin (2012). Beyond Racialized Representation: Architectural Linguae Francae and Urban Histories in the Kampung Houses and Shophouses of Melaka and Singapore. In M. Desai and M. Rajagopalan (Eds.), Colonial Frames, Nationalist Histories (pp. 213252). Burlington, VT: Ashgate.

Tajudeen, I. bin (2010). Kampong Gelam, Rochor and Kallang: the old Port Town. In A. Ng and B. Platzdasch (Eds.) Malay Heritage of Singapore (pp. 56-69). Singapore: Malay Heritage Foundation.

Tan, P. P. (Director). (2014). To Singapore, with Love [Motion Picture].

Tan, P. P. (Director). (2017). In Time to Come [Motion Picture].

Wong, Y. C., \& Tan, K. L. (2006). Emergence of a cosmopolitan space for culture and consumption: the new world amusement park-Singapore (1923-70) in the inter-war years. Inter-Asia Cultural Studies, 5(2), 279-304.

Yeoh, B. S., \& Kong, L. (1994). Reading Landscape Meanings: State Constructions and Lived Experiences in Singapore's Chinatown. Habitat International, 18(4), 17-35.

Yeoh, B., \& Huang, S. (1996). The conservation-redevelopment dilemma in Singapore: The case of the Kampong Glam Historic District. Cities, 13(6), 411-422. 